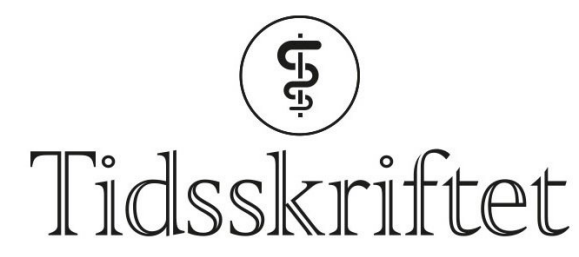

DEN NORSKE LEGEFORENING

\title{
Ord som kommer og ord som går
}

SPRÅKSPALTEN

\section{ERLEND HEM}

E-post: erlend.hem@medisin.uio.no

Erlend Hem er professor dr.med., fagsjef og redaktør for Tidsskriftets språkspalte.

Noen ord oppstår ved en misforståelse, og noen er døgnfluer.

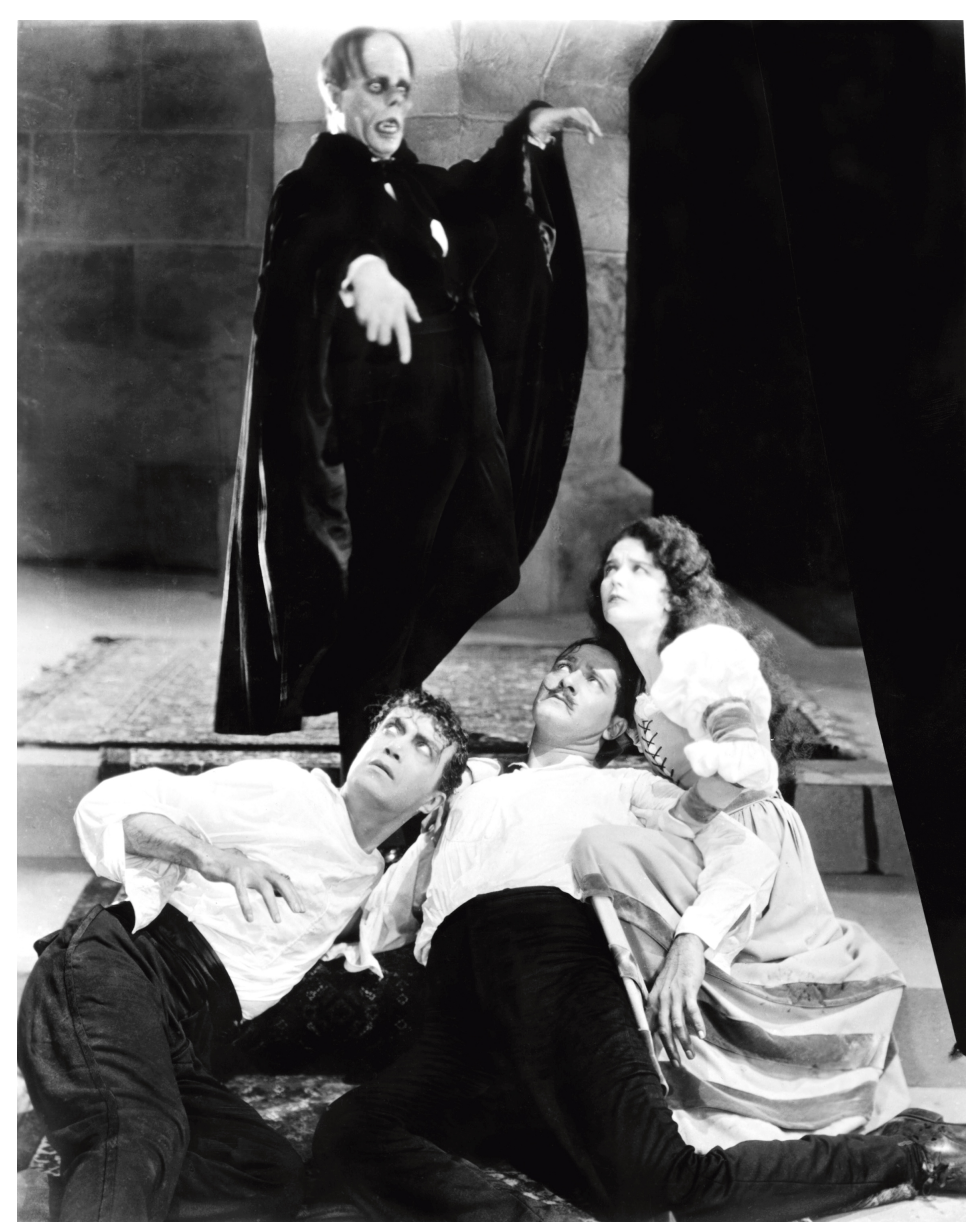

Lon Chaney som Operafantomet i stumfilmen fra 1925 med samme navn. Foto: Everett Collection / NTB scanpix

I medisinen kjenner vi ordet fantom i flere sammenhenger. Det kan værefantomsvangerskap, et innbilt svangerskap, eller fantomsmerter, som er smerter som synes å komme fra en amputert kroppsdel. Fra undervisningen i fødselshjelp husker vi fantomet, ei dokke som ble brukt for å vise fosterets bevegelse gjennom bekkenkanalen (1).

I ordboka står det at fantom kommer fra gresk fantasma ‘drømmesyn', og at det er beslektet 
med ordet fantasi (1). Det er altså noe som ikke er helt virkelig. På samme måte har vi fantomord, som oppstår for eksempel ved feillesning eller sammenblanding (2). Et eksempel er henspeile, som er en sammenblanding av henspille på og gjenspeile (3). Det finnes en rekke slike ord som mange bruker, men som ikke står i ordbøkene (4). Vanlige eksempler er nitidig i stedet for nitid, viderekommende for viderekomne (5), forhåndsregel for forholdsregel (6) og innkorporere for inkorporere (5). Denne gruppa er altså nokså sammensatt. Det kan dreie seg om nydanninger som skyldes sammenblandinger av ord, slik som henspeile, men også det som vil være brudd på rettskrivning, som innkorporere.

\section{Ord som forsvinner}

Hver dag dukker nye ord opp - og forsvinner igjen. De er døgnfluer som tjener en hensikt der og da, men som så blir borte. Det finnes mange slike eksempler. Hjerneflue ble brukt av Johan Sebastian Welhaven (1807-73) om en 'fiks idé' (7). Ordet er i grunnen ganske godt, men kom ikke ordentlig i bruk. Et annet eksempel er gaustadkandidat. Da jeg hørte det første gang, trodde jeg det dreide seg om en lege som fikk sin spesialistutdanning ved Gaustad sykehus, men slik er det ikke. Det handler om en person som er 'moden for sinnssykeasylet' - synonymet er gaustadgal (8). Det er brukt av Arne Garborg (1851-1924) og noen få andre, men er nå borte. Både hjerneflue og gaustadkandidat er eksempler på rariteter som knapt finnes i moderne norske ordbøker (7). En variant av dette er faguttrykket hapax legomenon, som er ord som kan påvises bare ett sted i litteraturen (9).

Ord blir borte også fra medisinsk terminologi (10). De har tjent sin hensikt i kortere eller lengre tid, men så trenger vi dem ikke mer. Ord som radesyke, sott, nervefeber og feberkrise var viktige i sin tid, men ikke nå.

\section{LITTERATUR:}

1. Fantom. I: Det norske akademis ordbok. https://naob.no/ordbok/fantom Lest 28.4.2020.

2. Fantomord. I: Stor norsk ordbok. https://www.ordnett.no/search?searchfantomord\&langno Lest 28.4.2020.

3. Hem E. Smittsom speiling. Tidsskr Nor Legeforen 2010; 130: 1502. [CrossRef]

4. Språkrådet. Feil bruk av ord og uttrykk. https://www.sprakradet.no/sprakhjelp/Skriverad/Feil-bruk-av-ord-og-uttrykk Lest 28.4.2020.

5. Gundersen D. Fantomord. Tidsskrift for Norsk psykologforening 2012; 49: 80. https://www.psykologtidsskriftet.no/index.php?seks_id=163284\&a=3 Lest 28.4.2020.

6. Hem E. Forholdsregler og smittevern. Tidsskr Nor Legeforen 1994; 114:3356.

7. Senje AA. Fypike gjorde selbureis i røytemåneden. Språknytt 2013; 41: 28-30.

https://www.sprakradet.no/Vi-og-vart/Publikasjoner/Spraaknytt/Arkivet/spraknytt-2013/Spraknytt-1201 3/Fypike-gjorde-selbureis-i-roytemaneden Lest 28.4.2020.

8. Gaustadkandidat. I: Norsk riksmålsordbok. https://www.ordnett.no/search?searchgaustadkandidat\&langno Lest 23.7.2015.

9. Hapax legomenon. I: Stor norsk ordbok. https://www.ordnett.no/search?languageno\&phrasehapax\%2olegomenon Lest 28.4.2020.

10. Nylenna M. Ord og uttrykk som forsvinner. Tidsskr Nor Legeforen 2019; 139. doi: 10.4045/tidsskr.19.0o07. [CrossRef]

Publisert: 15. juni 2020. Tidsskr Nor Legeforen. DOI: 10.4045/tidsskr.20.0385

(C) Tidsskrift for Den norske legeforening 2020. Lastet ned fra tidsskriftet.no 